\title{
Films, Subtitles and Subversions
}

\author{
Elena Di Giovanni \\ University of Macerata, Italy
}

Focusing on subtitling for film festivals, more specifically on an Italian festival on human rights, this paper centres upon the notion of subversion as it can be applied to the practice of subtitling in this very special field. Subversive practices can, in fact, be found at various levels in the overall activity which the international distribution of films through festivals entails. From the very production of films and videos which tend to upturn mainstream cinematic conventions to the translation and dissemination of texts denouncing the violation of rights, the subversive action carried out by film festivals is always visible, strong and steady.

Laying emphasis on the often unacknowledged role of the subtitlers involved in these subversive actions, the paper attempts to highlight the unique and often very complex role they are required to play, as well as the linguistic, sociocultural and emotional constraints they have to face.

\section{The paradox of film festivals}

I festival non sono il contenitore ma il contenuto, i film sono lo strumento attraverso cui questo contenuto è riconosciuto socialmente; se tale riconoscimento mancasse, verrebbe meno anche la loro funzione (D’Antonio 2006)1.

[Festivals are not containers, they are the substance, and films are the tools for making this substance socially known and acknowledged. Should this acknowledgment not be achieved, festivals would lose their own function] (translation EDG).

Film festivals in Italy and a number of other European countries seem to be embedded in a series of paradoxes, or so declare several experts and agents involved in these events ${ }^{2}$. In practical terms, while many local cinemas are closing down, subjugated as they are to competition from multi-screen theatres and cinema villages, more and more small-scale festivals are being organized everywhere. In terms of the topics and issues raised, although they almost seem to tilt at windmills in the attempt to counter the increasing homogenisation promoted by most mainstream cinema and the multinationals beyond it, film festivals are gaining momentum and nowadays appeal to audiences from all walks of life. Moreover, even though they have seen a constant decrease of funding from the government, at least in Italy, they keep being on the increase.

The main reason for the growth of an activity whose very existence is hampered by a number of factors can, perhaps, be found in the opening 
quotation from D'Antonio: festivals are not merely containers, they are 'the substance'. They are tools for making 'new substance' known to the society at large, for raising awareness and fostering diversity. Diversity, in fact, seems to be the very essence of film festivals, which touch upon all sorts of issues, objectives and hopes. From the performing arts to the application of ultramodern technologies, from history to social and cultural development, a large number of film festivals attempt to give visibility to the invisible, to give voice to the unheeded, especially when they aim to denounce the violation of human rights like the international film festival which is under scrutiny in this paper.

In Italy, as Severino Salvemini ${ }^{3}$ declared in December 2006 at a conference held in Rome and organized by AFIC, Associazione dei Festival Italiani di Cinema (www.aficfestival.it), festivals are responsible for raising the viewers' taste and sensibility, for refining their active perception and bringing about innovative and experimental cultural content.

A similar claim has been recently made, through a different channel, by five American critics and producers of non-mainstream cinema and advocacy videos who have gathered their long-standing experiences in a book called Video for Change. A Guide to Advocacy and Activism (Gregory et al. 2005). Although the book mainly focuses on the production of videos and films which aim to shed light on unknown realities and unequal living conditions, the authors make ample reference to the growing importance and increasing dissemination of these audiovisual products, by stating, for instance, that "around the world, video is increasingly embraced as a tool to support education, reinforce cultural identity and encourage organizational and political participation" (ibid. 2005: 13). They refer specifically to film festivals and say that they represent a valuable opportunity to give visibility to a number of issues, but also to enhance a sense of community, to start discussion forums, to enable networking with press, general public and other filmmakers and, last but not least, to obtain media exposure, action and advocacy opportunities (2005: 249).

The strengths of film festivals, which are highlighted by the authors of Video for Change, seem to provide more than one reason to support the positive side of the paradox briefly described above. They also provide a good summary of the very essence of these cinematic events which, as we shall see later in this paper, are inextricably bound to the translational activity they entail.

International film festivals, as well as the translations which make them possible, seem to be strictly connected to another important issue: subversion. According to the Shorter Oxford English Dictionary, 'to subvert' means "to disturb or overthrow a system, a condition, a principle" (2003: 3094) and, interestingly enough, these actions are said to be carried out "especially by covert action" (ibid.). When it comes to translation, it seems plausible to state that subverting implies the upturning of a - textual and extratextual - status quo, the changing of a situation, but what is worth highlighting here is that this kind of subversion does not necessarily imply noisy, 
violent revolutions. If, as Maria Tymoczko and Edwin Gentzler state, "translation, like other cultural activities, can be mobilized for counterdiscourses and subversions" (2002: xix), this mobilization generally aims to "introduce new forms of representation" (ibid.), to the displaying of images and conveying of discourses which would not otherwise be able to emerge.

The subversive action carried out by film festivals with a focus on human rights is obviously non-violent; it is muted but incisive, slow but steady. These and other festivals find their raison d'être in the subversion of mainstream filmmaking and, most importantly, in the reshaping of film reception by giving as much visibility as possible to minor productions and by making them travel the world.

It goes without saying that the dissemination of non-mainstream films and videos is inextricably tied to translational activities. Even though it is hardly ever acknowledged, the impact of film festivals is very often enhanced by translation, most commonly by subtitling. Thus, subtitling is deeply involved in the subversive action carried out by film festivals with a focus on socio-cultural issues, and it also has its own subversive connotations. First of all, subtitling for these festivals implies coping with everchanging, hard working conditions, with the frequent lack of dialogue lists and any other support material, as well as with the need to restore meaning and make sense of the pivot titles which films from non-Western countries are very often supplied with. It also implies a strong emotional commitment on the part of the translator/subtitler, required as he or she is to deal with thorny issues and striking, hardly-ever-displayed images.

It is precisely in this twofold perspective that subversion is intended here and will be further discussed. The challenging impact of film festivals with a focus on socio-cultural issues, the debate which they start or fuel all over the world, are matched by the efforts made by the subtitlers to enhance this impact and bring it across to the world by facing numerous difficulties and constraints.

In the following sections, we shall attempt to explore the subversive power of subtitling for film festivals and the all-prominent, even though somewhat virtually unacknowledged role of the translator as mediator between subversive films and the audience, by making special reference to the Human Rights Nights International Film Festival. The latter is held every year in Bologna and Forlì, Italy, organized by the Cineteca di Bologna (Italy) with the support of Amnesty International, Unicef and Amref. We shall take into account two films which were part of the 2005 edition of the festival, whose subtitles were produced by graduate students attending a specialized degree course at the Advanced School of Foreign Languages for Interpreters and Translators of the University of Bologna at Forlì, as part of a training scheme on subtitling which involved practical activities.

However, before embarking on our analysis, we shall first of all explore several interesting approaches developed within translation studies over the last decade, with special reference to a few contributions which have striven to bring the translator to the fore and acknowledge his or her 
complex, often difficult tasks. We will then refer these observations to our case study and comment on a series of excerpts which ought to help unveil the silently, positively subversive nature of festivals on human rights, the strength of their claims and the unique subtitling activity which they imply.

\section{Subverting theoretical frameworks: translation studies, the media and human rights}

In an essay called "Translation and cultural identity", centred upon the social and cultural implications of translation from Français into Québecois, Annie Brisset talks about translation as a re-territorializing operation, "as an act of reclaiming, of recentering the identity" (2004: 340). Although Brisset's remarks stem from a very different context and set of texts, and their application to our case may appear difficult, at least in principle, Brisset's observations have some sort of indirect connection with the translational activity which is the object of this study and, most significantly, with its social and cultural role here emphasized. Translating films which focus on human rights and are produced within minority communities, to be subsequently distributed through festivals, certainly fosters the acknowledgement of 'other' territories, other identities, but also other feelings and emotions.

Later in her insightful essay, as she refers to the important role played by the translation of great, international literary works into Québequois, Brisset makes another interesting remark which, once again, can be applied to our case. She states that the goal of a translation is not so much to provide an introduction to the "other", be it a culture, a small group of people or the acknowledgement of their living conditions, but rather that "it is the foreign work which is given a mission" (2004: 341). This mission, in Brisset's case, implies providing a respectable status for minor languages, but it can also refer to giving visibility to normally neglected issues, realities and communities, as happens with films which are centred upon the respect and violation of human rights.

On the whole, the position held by Brisset has some subversive connotations to it, as it claims a strong, positive role for foreign texts in the representation of minority cultures and identities. Obviously, such a role is enhanced by translation, whose mission is to put in the spotlight the foreign text and ensure that it is disseminated well beyond local boundaries. Moreover, Brisset's paper also works in the direction of an indirect dismissal of some old-fashioned views on translation, which nowadays prove too limited in scope and applicability, especially when it comes to analysing new translational activities and their social and cultural impact.

In order to better understand Brisset's position with regards to the past and future of translation studies, and to make reference to the translational activity here under scrutiny, let us very briefly look at this discipline from a historical perspective. At the onset of systematic research into this field, and for a rather long time afterwards, scholars were mainly concerned 
with defining prescriptive formulas which could help explain and direct translational phenomena as much as possible. They were not so much interested in the context of text production, but only in analysing language pairs, classifying linguistic features, and the like ${ }^{4}$. At a later stage, under the impetus provided by a 'second generation' of researchers, a new, descriptive approach was brought to the fore, so as to try and account for regularities in translation processes and products by taking into account the relevant social context ${ }^{5}$.

In more recent years, scholars have started to look at - and reflect on - translational phenomena from a much broader perspective, so as to encompass new translation practices (like those connected to the audiovisual media) but also take into account an increasing number of behavioural, social and, most of all, cultural factors which have a strong influence on translation. In this sense, many scholars who had initially supported the descriptive approach have, more recently, geared their research towards new, interdisciplinary avenues which are imbued with social and cultural considerations. And what is most important for this study is that, by seeing translational activities as embedded in cultural contexts, some of them have brought to the fore the potentially subversive role of translation in crosscultural, non-Western-centred relations. This is the case, for instance, with an important contribution by Theo Hermans, one of the main promoters of the move from prescriptive to descriptive approaches in translation studies in the eighties, who subsequently shifted his interest towards the intercultural role and communicative force of translation. As Hermans sums up in an essay for a volume entitled Translation, Power and Subversion (1996: 26),

translation used to be regarded primarily in terms of relations between texts, or between language systems. Today it is increasingly seen as a complex transaction taking place in a communicative, socio-cultural context.

More interestingly, in the sentence which follows the quotation above Hermans lays emphasis on the translator and his active, socio-culturally determined role: "This requires that we bring the translator as a social being fully into the picture" (ibid.).

This all-important, somewhat revolutionary approach has lately been shared by other scholars ${ }^{6}$, as can also be seen in the other contributions to the volume which contains Hermans' essay and whose title is, obviously, at the heart of the present paper. A strong emphasis on the translator as social agent and communicator was, in fact, rather new to translation studies in the mid-nineties, although there have been a few theoretical approaches which, more or less at the time of publication of Translation, Power, Subversion, have favoured a closer evaluation of the translator's role in different settings ${ }^{7}$. This volume, edited by Román Álvarez and Maria Carmen África 
Vidal, precisely centres on the translation of subversive texts and, by calling into play different viewpoints and perspectives, it focuses on the role of the translator in relaying subversive attitudes ${ }^{8}$. By bringing it to the fore in each reflection upon the nature and impact of cross-cultural communication, be it through paper or a screen, contributors to Translation, Power and Subversion seem to have carried out a subversive action towards the very discipline they work within, i.e. translation studies, while fostering a new, 'human perspective' which can lead to interesting discoveries. As the volume editors point out in the introduction,

Translators are constrained in many ways: by their own ideology; by their feelings of superiority or inferiority towards the language in which they are writing the text being translated; by the prevailing poetical rules at that time; by the very language in which the texts they are translating is written; by what the dominant institutions expect of them; by the public for whom the translation is intended. (1996: 6)

Most of these constraints are essential for translators who find themselves involved in subtitling for film festivals, all the more so when the object of interlingual and intercultural transfer are texts which focus on human rights, feelings and experiences. The translators' ideology ${ }^{9}$, the shared values they have acquired within society, play a primary role in determining their approach to the text being subtitled. But sometimes the text feeds back into the translators' ideology by revising it, by subverting it in the light of the knowledge acquired through the text itself. Audience expectations are equally essential in determining the translators/subtitlers' attitude towards their tasks, especially as they bear the burden of giving visibility to unshared opinions and violated rights.

By way of conclusion of this brief overview, it is worth mentioning that - and this is certainly not by chance- the emphasis on the translator is to be found also in a text devoted to the translation of human rights through legal documents but also through a variety of other text types. In Human Rights in Translation (1999), Marianne Garre focuses on three theoretical standpoints which she deems particularly relevant for the translation of texts with a focus on human rights. Among them is the so-called hermeneutic approach to translation, which Garre borrows from the theories developed by Hans-Georg Gadamer and, more specifically, by Radegundis Stolze. In line with the views briefly described above, and also with our case in point, Garre states that in hermeneutic translation theory the focus is on the translator (ibid.: 78), his or her being an individual who brings all of his or her linguistic and extralinguistic skills, his or her experiences and also his or her courage to the act of decoding and recoding of a text. Garre goes on to affirm that "the interesting part about this [translation] process is that it is not sufficient for the translator to understand the linguistic meaning of a text, he also has to understand any underlying meanings" (ibid.: 79), and to this we could add that the translator is certainly, though to different 
degrees, influenced by the text when its nature and its underlying meanings are subversive.

Focusing on the translator/subtitler while trying to explore the very special nature of subtitling for film festivals, in the next section we shall place emphasis on the technical, linguistic and cultural constraints which are at stake, but also on the emotional burden and personal involvement this activity entails. We shall do so with a view to claiming recognition for the work of subtitlers for film festivals, who work in invisible settings and are hardly ever mentioned by critics or scholars, and yet are largely responsible for the acknowledgement of the rights and feelings of many individuals.

\section{A subversive practice: subtitling for festivals, subtitling human rights}

When considering the translational activity connected to the distribution of films through national and international festivals on human rights, subversion can be first of all related to the conditions in which the subtitlers are required to work. Although it is still characterized by a lack of homogeneity, especially in countries which are traditionally attached to dubbing as the leading form of audiovisual translation (i.e. Italy), the practice of subtitling tends nowadays to reveal some common, recurring features, which several scholars have also attempted to describe ${ }^{10}$. And yet, if a certain regularity in working routines can be said to apply to the linguistic adaptation of television products, mainstream cinema and DVDs, when it comes to film festivals in general the subtitling process seems to follow a very different path, with virtually no standardized practice from the commissioning of the translation down to the final output of subtitles.

In Italy, for instance, films are very often supplied to subtitling agencies - or to individual subtitlers working as freelancers - in the form of poor quality videotapes, or occasionally DVDs. Dialogue lists are not always provided, and when they are, they are more often than not unreliable. It therefore occurs quite frequently that subtitlers are required to do their job relying mainly on the videos which, in the frequent case of films shot in languages not commonly known to the subtitlers, are accompanied by pivot titles in English. Moreover, the latter are frequently printed on the films in the country of origin and they can prove to be difficult to understand, in terms of language use as well as subtitling conventions. Therefore, subtitlers are required to make extra efforts to interpret the pivot titles - the uncommon, often ambiguous references which they may contain - and are compelled to carry out extensive research so as to interpret their 'awkward' source text and produce a smooth-running, clear subtitled version.

Since, as has just been said, films which travel through festivals are often provided with pivot titles and, most importantly, they have to be subtitled in a very short time and on tight budgets, in Italy it is still common to use a Windows-based software such as Power Point to type in the subtitles. 
These are then launched by the subtitlers themselves during screenings or, alternatively, by an operator who works side by side with them. All of these special features and requirements might be said to make the subtitlers' job more challenging, perhaps even more difficult than what happens in more standardized situations ${ }^{11}$, but they also, undoubtedly require a unique commitment, which affects the subtitlers' professional and personal sphere.

Let us now attempt to give evidence of what has been discussed so far by making reference to two films which were part of the 2005 edition of the Human Rights Nights International Film Festival. In the homepage of the festival website, the organizers claim that the main objective of the event is to "present filmmakers who use their camera as an instrument for a 'visual resistance', towards a better world"12. This is precisely what happens in the films we shall here briefly refer to, whose selection is due to their thematic and structural differences. The first two sets of examples are taken from a short Israeli film called A Different War, written and directed by Nadav Gal in 2003. Subsequently, examples will be taken from The Orphans of Nkandla (2005), a longer and perhaps cruder South African documentary film which was shot by Brian Woods for the BBC in Zululand, South Africa.

To give a short description of the working conditions the trainee subtitlers who were asked to translate these and other films were required to comply with, let us first of all highlight that they received the films in poor quality videotapes, which had already been copied several times and whose images were sometimes barely visible. Only occasionally were the videotapes accompanied by dialogue lists, and these were often incomplete, rough versions of the scripts. The students had to work individually, at home, using a Power Point template to insert the subtitles, which they were subsequently required to launch on the occasion of the film screenings, before very large audiences. Upon completion of their training, the six students who worked as subtitlers for the 2005 edition of the Human Rights Nights Film Festival were administered a questionnaire ${ }^{13}$, which revealed their satisfaction in terms of the technical and translational expertise acquired but also their increased awareness of important issues related to the respect of human rights and the claim for identity recognition in various parts of the world.

The first of the two films ( $A$ Different War) is centred upon the story of a young boy who is about 10 years old and is forced to come to grips with the issue of warfare in Israel while also fighting his own, inner battle with his homosexuality. Noni lives with his mother and an older brother, Zahi. While their father is in training to prepare for new attacks against the Palestinians, Noni's brother Zahi and his friends try to make their small contribution to the never-ending battle and show support to their fathers by climbing a high cement wall which divides the Israeli and Palestinian territories and shouting insults to the Palestinians. The film mainly revolves around the twofold battle fought by Noni, against his inner feelings as well as against his natural tendency to reject the warfare attitude which Israeli men are generally brought up with. Almost without talking, Noni seems to claim 
throughout the film his right to be different, in terms of his sexuality as well as his political commitment.

The following two tables feature excerpts from the English pivot titles of A Different War, matched by those provided by the Italian subtitler ${ }^{14}$. The first set of examples is taken from the opening scene of the film, which sees Noni in his house while gunfire and bombs are erupting outside. Noni's mother tries to reassure him explaining that the noise they hear is mainly caused by technicians who are installing the security window systems. However, the boy appears to be deep in thought and is somewhat frightened, even if not directly from the bombshell and gunfire.

Table 1

\begin{tabular}{|l|l|}
\hline $\begin{array}{l}\text { Were you frightened? - A little } \\
\text { - Don't be afraid, sweetheart, }\end{array}$ & - Ti sei spaventato? \\
\hline $\begin{array}{l}\text { It's only the people who came } \\
\text { to install the security windows. }\end{array}$ & Non aver paura tesoro, stanno solo \\
installando le finestre di sicurezza.
\end{tabular}

As can be seen, the two subtitle blocks reveal several mistakes in the use of punctuation, subtitling conventions as well as in the use of English. By inserting three short turns in one block, two of them in the same line without a dash at the very beginning, and by omitting the full stops at the end of the second and third line, subtitling conventions are broken and the overall perception of the exchange is hampered. Moreover, what makes it even more difficult for viewers to follow the exchange through the subtitles is the quick pace at which lines are uttered by the two characters. The Italian subtitled version attempts to restore some clarity by moving the second line uttered by Noni's mother ("Don't be afraid, sweetheart, it's only the people who came to install the security windows") to the following block, so as to give more coherence to the discourse.

The two subtitle blocks featured in Table 2 appear at the very beginning of a sequence which shows Noni's school teacher in class, reading from a religious book while her pupils are writing. The sequence starts rather abruptly, after a cut from the previous scene in which Noni, his mother and brother were in their house talking on the phone to Noni's father.

Table 2

\begin{tabular}{|l|l|}
\hline $\begin{array}{l}\text { he turns to God and asks him } \\
\text { to give him back his strength, }\end{array}$ & $\begin{array}{l}\text { Si volta verso Dio e Gli } \\
\text { chiede di ridargli la sua forza, }\end{array}$ \\
\hline $\begin{array}{l}\text { then Samson pushes the pillars } \\
\text { and the walls of Gaza tumble... }\end{array}$ & $\begin{array}{l}\text { poi Sansone spinge le colonne } \\
\text { e le mura di Gaza crollano. }\end{array}$ \\
\hline
\end{tabular}

As the English subtitles clearly show, the perception of the sudden scene change is made difficult because there is no capital letter at the very beginning of the first subtitle, as if the teacher's speech continued from something which had been said before. Incidentally, also the transition from this to the 
following scene is confusing because of the use of suspension marks at the end of the second block, which in fact corresponds with the teacher's shift to a different topic and activity. The subtitler has, first of all, attempted to restore some clarity in the use of personal references but, as she declared in her questionnaire, she decided not to move the direct reference to Samson in the previous block, since the viewers would have found no corresponding reference in the English subtitle printed on the film. However, she eliminated the suspension marks at the end of the second block and replaced them with a full stop, so as to clearly mark the shift to another topic.

With the two excerpts from The Orphans of Nklanda (2005) presented below, we aim to shift from the observation of technical and linguistic difficulties to some more general considerations on the emotional implications of subtitling films for festivals, especially those which aim to denounce the violation of rights or unfair -inhuman- living conditions. Thus, before discussing the two excerpts below, let us briefly linger on the position of the translators/subtitlers and their role in transferring strong feelings, emotions and attitudes. This aspect, which may occasionally apply to other experiences in audiovisual translation ${ }^{16}$, is in fact always involved in the adaptation of films and videos which have originated within minority communities and which imply a certain amount of subversion, in terms of production as well as the issues they address. As a matter of fact, the injustices they denounce, or the burning issues they reveal, give life to emotionally-dense dialogues which place yet another burden on the subtitlers. Not only are the latter required to find the most suitable rendering of the original words in the target language, but also to make strong issues visible and powerful outcries resounding. All this, of course, while also having to cope with their own, personal involvement

In the case of the 2005 edition of the Human Rights Nights Film Festival, the six students working as subtitlers were engaged in the adaptation of very strong, often shocking tales about infringed human rights and deep inner conflicts. Among the most widely acclaimed films were, for instance, The Other Side of the Burka, an Iranian documentary film which denounces the uncivilised conditions of women living in certain regions of Iran; Promised Land, which documents human trafficking between Eastern Europe and Israel through a number of interviews and real-life shots, and finally $\mathrm{Or}$ phans of Nkandla, which focuses on the deadly impact of AIDS in South Africa and the living conditions of the 750,000 children who have been orphaned by the disease ${ }^{17}$. The film has comments in English while interviews and dialogues are in the Zulu language, accompanied by subtitles. As the documentary was produced by the BBC, the English pivot titles are of good quality and do not reveal mistakes in terms of subtitling conventions, segmentation, etc.

Besides portraying the ravaging effects of AIDS within the small rural community of Nkandla, the film focuses specifically on the lives of two young girls, who are about 9 years of age and have been forced out of childhood by the loss of one or both parents through AIDS. 
Table 3 features four blocks of subtitles which accompany the words of young Nobuhle. Her father died a few months earlier and her mother is very ill. She has a large number of younger and older brothers and sisters, of whom she has to take full care. According to the severe rules of the Zulu society, being the oldest girl she has to leave school and work for the whole family, even striving to find food for everyone. She suffers from heavy stomach aches but nobody seems to care, her brothers even laugh at her when she has to rush to the toilet like her sick mother does. Talking to the camera and always keeping her eyes down, she confesses the fears of an eight-year-old who has been forced to grow up too fast and come to terms with death.

Table 3

\begin{tabular}{|l|l|}
\hline $\begin{array}{l}\text { Today I didn't go to school } \\
\text { because I have a tummy ache }\end{array}$ & $\begin{array}{l}\text { Oggi non sono andata a scuola } \\
\text { perché ho mal di pancia. }\end{array}$ \\
\hline $\begin{array}{l}\text { I get scared when my tummy is not } \\
\text { right }\end{array}$ & Mi spaventano questi dolori, \\
\hline $\begin{array}{l}\text { When I run to the toilet } \\
\text { my brother says I have AIDS }\end{array}$ & $\begin{array}{l}\text { ogni volta che corro in bagno, } \\
\text { mio fratello dice che ho l'AIDS }\end{array}$ \\
\hline and I'm afraid it's a killer & e io ho paura che mi ucciderà. \\
\hline
\end{tabular}

Apart from the lack of punctuation in the English pivot titles, which might be part of a set of strategies defined by the producers, there seem to be no other complexities in the source version. Thus, the Italian subtitler was here only challenged by her own emotional commitment, provoked by the images which match the words above and which show the young and sad child against a black wall, speaking slowly and trying not to display her fears.

The same situation occurred when the translator/subtitler had to face the sequence in Table 4 . This portion of the text refers to the second story which Orphans of Nkandla is focused on: the life of another family ravaged by AIDS and the great hardships endured by Mbali, a 9-year-old girl whose mother passed away and whose father is condemned to the same fate. The English version transcribed below does not appear on screen in the form of subtitles, if not for the short exchange between Mbali and her father (block 3 ). The lines before this exchange are uttered by the English off-screen narrator (hence the italics), whereas those which follow are by Sister Hedwig, the nun who is actively engaged in the efforts to support the orphans of the South African community.

Table 4

\begin{tabular}{|l|l|}
\hline $\begin{array}{l}\text { As she gets up each morning, Mbali's } \\
\text { greatest fear }\end{array}$ & $\begin{array}{l}\text { Ogni mattina, al risveglio, } \\
\text { la più grande paura di Mbali }\end{array}$ \\
\hline $\begin{array}{l}\text { Is that her father may not have survived } \\
\text { the night }\end{array}$ & $\begin{array}{l}\text { è che suo padre sia } \\
\text { morto nella notte. }\end{array}$ \\
\hline - Dad? & - Papà? \\
\hline
\end{tabular}




\begin{tabular}{|l|l|}
\hline - Mbali... & - Mbali... \\
\hline $\begin{array}{l}\text { Mbali has not told their teachers } \\
\text { either that their mother has died }\end{array}$ & $\begin{array}{l}\text { Mbali non ha detto alle maestre } \\
\text { che la madre è morta, }\end{array}$ \\
\hline or that their father is ill & né che il padre è malato. \\
\hline $\begin{array}{l}\text { Children at school might start calling } \\
\text { them names. Your mother died of } \\
\text { AIDS, }\end{array}$ & $\begin{array}{l}\text { Gli altri bambini direbbero } \\
\text { "Se tua madre è morta di AIDS, }\end{array}$ \\
\hline so you might also die of AIDS & Anche tu morirai di AIDS". \\
\hline
\end{tabular}

When conveying this sequence into Italian subtitlers, the student ${ }^{18}$ who was given this film had a more challenging role to play. First of all, she had to rely solely on the videotape in order to understand and transcribe the English lines, since no dialogue list was supplied by the festival organizers. Secondly, as she pointed out in her questionnaire, she had to make huge efforts to understand Sister Hedwig's accent, as well as the voices of other South African characters throughout the film. Subsequently, she transferred the lines uttered by the two commentators to her subtitle template, using italics to emphasize that both are spoken off screen and adding punctuation to clarify the sequence of exchanges ${ }^{19}$.

However, as the trainee subtitler also stated in her questionnaire, the hardest part of her task was connected with the emotional intensity of the scene. Just before the short sequence featured in Table 4, Mbali is shown inside her house, sitting on the earth next to her little brother, whom she has to take care of. When Sister Hedwig asks her if she misses her mother, she utters a very weak "Yes" and starts sobbing, almost ashamed to display her feelings. She soon resumes her work and gives a bath to her little brother, who is also crying for the recent loss of their mother.

\section{Conclusion}

By way of conclusion, we refer back to the opening lines of this paper, and more precisely to the paradox in which film festivals have been said to be embedded, in Italy and beyond. A similar paradox seems, in fact, to enwrap the whole of the subtitling activity involved in the circulation of films through festivals. Although subtitlers are required to work according to unstable practices and are forced to come to grips not only with technical, linguistic and cultural constraints but also with a strong personal commitment, subtitling for film festivals is on the increase. The overall activity of translation, adaptation and launching of subtitles is required in an increasing number of situations and for a host of new events.

And perhaps this leads us to an important discovery: subversions are best originated and enhanced by paradoxical situations. Or, if this is not always the case, we can state with a higher degree of certainty that when it comes to translation, especially one of its most popular derivative forms such as audiovisual translation, subversive practices can produce positive effects. 
Having found traces of subversion in some recent trends in translation studies, we have seen that subversive attitudes are effectively fostering new perspectives, new research paths and enhancing a renewed role for the translator as linguistic, cultural and social mediator. Then, having considered the scope of film festivals, the nature of the subtitling activity which they involve and the very active role of the translator/subtitler, we have come to the conclusion that such an activity may certainly pose difficulties and may require a strong, personal involvement on the part of the subtitlers, but it nonetheless succeeds in the task of shedding light on often neglected issues as well as on the identities, expectations and hopes of others.

Thus, as has been stated elsewhere ${ }^{20}$, subtitling for film festivals often implies a passage from darkness to light. It has positive effects on the overall activity of subtitling, adding value to it and making it more visible, but it also enhances the subtitlers' professional and personal accomplishment. As a matter of fact, not only does subtitling for festivals, by teaching subtitlers to tackle all sorts of difficulties, provide a good launching pad for those who wish to make a career in audiovisual translation, it also compels them to come to grips with the attitudes and feelings of humans from all corners of the world, making each subtitling enterprise an experience for life.

\section{Bibliography}

Alvarez, Roman and Maria Carmen Africa Vidal (eds) (1996). Translation, Power and Subversion. Cleveland: Multilingual Matters.

Baker, Mona (2006). Translation and Conflict. London/New York: Routledge.

Bassnett, Susan (1996). "The Meek or the Mighty: Reappraising the role of the translator". R. Alvarez \& M. C. A. Vidal (eds). Translation, Power and Subversion. Cleveland: Multilingual Matters, 10-24.

Brisset, Annie (2004). "The Search for a Native Language. Translation and Cultural Identity". L. Venuti (ed.). The Translation Studies Reader ( $2^{\text {nd }}$ ed.). London/New York: Routledge, 337-368.

Calzada Pérez, Maria (2003). A Propos of Ideology. Translation Studies on Ideology - Ideologies in Translation Studies. Manchester: St. Jerome.

Catford, J. C. (1965). A Linguistic Theory of Translation. London: Oxford University Press.

D'Antonio, Peppe (2006). "Il Festival e il Cinema: le Culture Ingabbiate". Introduction to the conference La Promozione del Sistema Cinema: il Ruolo Culturale dei Festival, Rome http://www.aficfestival.it/Convegno\%20Roma/D\%27AntonioRelazione.doc. (last visited on 18 December 2006).

Di Giovanni, Elena (forthcoming). "Subtitling the rights of humans". C. Bucaria, D. Chiaro \& C. Heiss (eds). Between Text and Image. Updating Research in Screen Translation. Amsterdam: John Benjamins.

Gadamer, Hans-Georg (1976). Philosophical Hermeneutics. Berkeley: University of California Press.

Garre, Marianne (1999). Human Rights in Translation. Handelshøjskolens Vorlag: Copenhagen Business School Press.

Gregory, Sam et al. (eds) (2005). Video for Change. A Guide for Advocacy and Activism. London \& Ann Arbor: Pluto Press.

Gutt, Ernst-August (1991). Translation and Relevance: Cognition and Context. Oxford: Blackwell ( $2^{\text {nd }}$ edition 2000, Manchester: St Jerome).

Hatim, Basil and Ian Mason (1997). The Translator as Communicator. London/New York: Routledge.

Hermans, Theo (1996). "Norms and the Determination of Translation". R. Alvarez \& M. C. A. Vidal (eds). Translation, Power and Subversion. Cleveland: Multilingual Matters, 25-51. 
Ivarsson, Jan and Mary Carroll (1998). Subtitling. Simrishamn: TransEdit HB.

Katramitroglou, Fotios (1998). "A proposed set of subtitling standards in Europe", in Translation Journal. Volume 2(2). http://accurapid.com/journal/04stndrd.htm. (last visited on 10 December 2007).

Nornes, Abé Mark (2004). "For an abusive subtitling". L. Venuti (ed.). The Translation Studies Reader ( $2^{\text {nd }}$ edition). London/New York: Routledge, 447-469.

Salvemini, Severino (2006). "Impatti conomici, sociali e culturali dei festival. Il Gioco Vale la Candela?". Paper presented at the conference La Promozione del Sistema Cinema: il Ruolo Culturale dei Festival, Rome (18 December 2006). www.aficfestival.it. (last visited on 10 December 2007).

Stolze, Radegundis (1992). Hermeneutisches Übersetzen. Linguistische Kategorien des Verstehens und Formulierens beim Übersetzern. Tübingen: Gunter Narr Verlag.

Turner, Graham (1993). Film as a Social Practice. London/New York: Routledge.

Trumble, William and Angus Stevenson (eds). Shorter Oxford English Dictionary ( $5^{\text {th }}$ edition). Oxford: Oxford University Press.

Tymoczko, Maria and Edwin Gentzler (2002). Translation and Power. Amherst/Boston: University of Massachusetts Press.

Venuti, Lawrence (1995). The Translator's Invisibility. Studies in Literary Translation. London/New York: Routledge.

Vinay Jean Paul and Jean Darbelnet (1958, $2^{\text {nd }}$ edition 1977). Stylistique Comparée du français et de l'anglais. Méthode de Traduction. Paris: Didier.

\section{Filmography}

Orphans of Nkandla (2003)

UK

Dir. Brian Woods

A Different War (2003)

Israel

Dir. Nadav Gal

The Other Side of the Burka (2004)

Iran

Dir. Mehrdad Oskouei

Promised Land (2004)

Israel/France

Dir.Amos Gitai

http://www.aficfestival.it/news.htm (last visited on 10 December 2007).

2 Most of the information presented here has been obtained through interviews and conversations with directors and operators involved in the production of film festivals, as well as with directors of subtitling firms and subtitlers. This has occurred during and after the work carried out within a research project on the quality of subtitling in Italy, developed at the Advanced School of Foreign Languages for Interpreters and Translators of the University of Bologna at Forlì, Italy.

3 Severino Salvemini is an eminent Italian scholar working at the Bocconi University in Milan. He is pro-rector of the same University and an expert in social communication.

4 See, for instance, the works of scholars throughout the 1960s, who came upon the study of translation from linguistic-driven research paths. This is the case for J. P. Vinay and J. Darbelnet or J. C. Catford, whose contributions were nonetheless precious for the future developments of translation studies.

5 See the work of Gideon Toury and the Manipulation School, carried out mainly in the 1980s and early 1990s.

6 See, for instance, Maria Tymoczko and Edwin Gentzler's book Translation and Power (2002) and, more recently, Mona Baker's extremely valuable text Translation and Conflict (2006). 
7 See, for instance, Ernst August Gutt's (1991 and 2000) attempt to shed light on the mental processes of the translators in carrying out their tasks, or Lawrence Venuti's strong advocacy for the translator's visibility in the context of literature (1995).

8 A very interesting approach is set forth by Susan Bassnett (1996) in her article "The Meek or the Mighty: Reappraising the Role of the Translator", pp.10-24.

9 "The translator acts in a social context and is part of that context. It is in this sense that translating is, in itself, an ideological activity" (Hatim and Mason 1997: 146). For a more detailed discussion of the ideology of translating and the translation of ideology, see Hatim, Basil and Ian Mason (1997) "Ideology", in The Translator as Communicator. London/New York: Routledge, pp. 143-163. For a variety of up-to-date approaches to the manifold relationship between ideology and translation see Calzada Pérez, Maria (2003) A Propos of Ideology. Translation Studies on Ideology - Ideologies in Translation Studies. Manchester: St Jerome.

10 Among the scholars who tried to map the use of subtitling conventions in Europe, interesting contributions were given by Jan Ivarsson and Mary Carroll in their book Subtitling (1998), but also by Fotios Katramitroglou in his paper "A proposed set of subtitling standards in Europe" (1998).

11 Even in a dubbing country like Italy, the subtitling of documentary series for satellite channels, for instance, is performed according to more or less standardized routines (in terms of delivery times, video formats, use of graphic conventions, etc.) defined by the various agencies which provide these services.

$12 \mathrm{http} / / /$ www.humanrightsnights.org/. (last visited on 10 December 2007).

13 The questionnaire was administered by the author of this paper to all the students involved in the project, within a month of completion of their work. The results of the questionnaire have been extensively used to comment on the strategies and choices made by the subtitlers of the two films here presented. For reasons of space, a full account of the questionnaire results cannot be given here.

14 A Different War was subtitled by Tiziana Forciniti.

15 Since the meaning and structure of the Italian subtitles quoted here and afterwards are very similar to those of the original English sentences, no back translation has been provided.

16 This is the case for the translation of films with a strong emotional impact, of documentary series on natural disasters, on serious diseases, etc.

${ }^{17}$ For more information, and to find out more about the positive aftermath of the film international distribution, see http://www.truevisiontv.com/orphans/. (last visited on 10 December 2007).

18 Orphans of Nkandla was subtitled by Alessandra Valente.

19 Talking about this particular sequence, the student stated that she did her best to produce subtitles which could enhance the perception of the film by Italian viewers. The two lines by the narrator and by Sister Hedwig are, in fact, uttered while several other voices can be heard. Those voices belong to the Zulu children and teachers who are shown to be in school while the lines are spoken.

${ }^{20}$ To this purpose, see Di Giovanni, Elena (forthcoming) "Subtitling the rights of humans", in Bucaria, Chiara, Delia Chiaro and Christine Heiss (eds) Between Text and Image. Updating Research in Screen Translation. Amsterdam: John Benjamins. 